\title{
Plant Volatiles Reduce the Viability of the Root-Knot Nematode Meloidogyne incognita Either Directly or When Retained in Water
}

Julio Carlos P. Silva, ${ }^{\dagger}$ Vicente P. Campos, and Aline F. Barros, Department of Plant Pathology, Marcio P. Pedroso, Department of Chemistry, and Willian C. Terra, Liliana E. Lopez, and Jorge T. de Souza, ${ }^{\dagger}$ Department of Plant Pathology, Universidade Federal de Lavras, Lavras, MG, 37200-000, Brazil

\begin{abstract}
Volatile organic compounds (VOC) produced by green residues for the management of plant-parasitic nematodes are poorly studied for oilseed plants and some Brassica spp. To investigate the activity of VOC in vitro and as biofumigants, dry and aqueous macerates of broccoli (Brassica oleracea var. italica) shoots and sunflower (Helianthus annuus) seed were used against the root-knot nematode Meloidogyne incognita. VOC produced by sunflower seed caused higher mortality of $M$. incognita second-stage juveniles $\left(\mathrm{J}_{2}\right)$ than VOC produced by broccoli shoots but both plant species were equally effective in decreasing the infectivity and reproduction of this nematode. The number of galls and eggs produced by the nematode in tomato roots was reduced by 89 and $95 \%$, respectively, on average, at the highest concentrations of broccoli and sunflower seed macerates tested as biofumigants. When nematodes were placed in water exposed to broccoli VOC, $\mathrm{J}_{2}$ immobility increased and the number of galls and eggs produced by the nematode in tomato roots

decreased 80 and $96 \%$, respectively. Water exposed to sunflower seed VOC had no effect on the viability of the nematode. Gas chromatography was used to identify five and six chemical groups in broccoli and in sunflower seed macerates, respectively, but only alcohols, sulfurated VOC, and terpenes were detected in the water exposed to these plant macerates. Sulfurated VOC from the water exposed to broccoli macerates were found to be involved in its activity against $M$. incognita. The purified VOC dimethyl disulfide (DMDS) and 3-pentanol were tested directly against $J_{2}$ and showed a lethal concentration of 176 and $918 \mu \mathrm{g} / \mathrm{ml}$ (ppm), respectively, whereas dimethyl sulfide had no effect against $M$. incognita. Furthermore, DMDS and 3-pentanol retained in water killed $\mathrm{J}_{2}$ and reduced gall formation and the number of eggs of $M$. incognita on tomato roots. Both these plant species produced toxic VOC to $M$. incognita, whereas only VOC retained in water exposed to broccoli had activity against $M$. incognita.
\end{abstract}

The root-knot nematode Meloidogyne incognita causes economic damage to a wide range of economically important crops and is considered one of the most significant plant pathogens in agriculture worldwide (Abad et al. 2008; Jones et al. 2013; Trudgill and Blok 2001). The control of this plant-parasitic nematode has been achieved by the application of chemical nematicides when plant resistance is not available. There is a great interest in using environmentally friendly strategies to control plant-parasitic nematodes such as plant amendments, green fertilization, or biofumigation (Caboni and Ntalli 2014; Oka 2010; Ploeg 2000).

Animal and plant residues have been applied as soil amendments to control a wide range of soilborne pathogens, including nematodes (Bailey and Lazarovits 2003). One such strategy is biofumigation. In this method, plant residues are incorporated into the soil and the chemical compounds with biocidal activity released during tissue degradation control pathogens. Some of these toxic chemicals are volatile organic compounds (VOC), which are gases or liquids that may evaporate under normal conditions of temperature and pressure. VOC are characterized by having carbon in their composition, low boiling points, and a lipophilic nature (Baldwin et al. 2006; Heil and Ton 2008; Loreto et al. 2014). The production of VOC is influenced by environmental conditions, availability and source of nutrients, oxygen, moisture, and the microbial community (Dudareva

${ }^{\dagger}$ Corresponding authors: J. C. P. Silva; E-mail: julioufla@yahoo.com.br; and J. T. de Souza; E-mail: jorge.souza@dfp.ufla.br

Funding: We gratefully acknowledge the financial support provided by Fundação de Amparo à Pesquisa do Estado de Minas Gerais, Coordenação de Aperfeiçoamento de Pessoal de Nível Superior, and Conselho Nacional de Desenvolvimento Científico e Tecnológico.

*The $\boldsymbol{e}$-Xtra logo stands for "electronic extra" and indicates that one supplementary figure is published online.

Accepted for publication 24 May 2018.

@ 2018 The American Phytopathological Society et al. 2013; Insam and Seewald 2010; Leff and Fierer 2008). Soil biofumigation is often done with residues of Brassica spp. because these plants contain glucosinolates that are converted into toxic compounds such as isothiocyanates (Ploeg 2008; Ploeg and Stapleton 2001). Examples include the use of mustard meal to control M. chitwoodi in potato and forage turnip (Brassica rapa var. rapa) and canola (B. napus) to control soilborne pathogens, including nematodes (Al-Rehiayani et al. 1999; Henderson et al. 2009; Potgieter et al. 2013). Thousands of VOC produced by plants are already known, representing around $1 \%$ of their secondary metabolites (Dudareva et al. 2006; Loreto et al. 2014). Different plant parts produce VOC with distinct ecological roles such as deterrents of herbivores (Dicke and Loon 2000) or with toxicity to plant-parasitic nematodes (Gu et al. 2007; Huang et al. 2010; Jardim et al. 2018; Zou et al. 2007).

Residues and the essential oil fractions of oil-producing species (also known as oleaginous plants) have shown activity against plant-parasitic nematodes (Oka et al. 2000a). Oilseed cakes such as sunflower (Helianthus annus) cakes may be used to control plantparasitic nematodes and fungi (Ganaie et al. 2011; Giudici et al. 2000; Tiyagi and Ajaz 2004). However, the VOC involved in the inhibition of pathogens were not identified.

Previous investigations have shown that some VOC produced by plants and microorganisms may be retained in the water, resulting in a toxic solution against plant-parasitic nematodes (Barros et al. 2014b; Grimme et al. 2007; Silva et al. 2017; Terra et al. 2017). Nematodes need water to move through the soil. Toxic VOC once retained in water may act as a liquid nematicide. However, few studies in vivo were done to investigate the water exposed to VOC (Terra et al. 2018).

In this study, our goals were to determine the effects of VOC from broccoli shoot and sunflower seed macerates against $M$. incognita. Nematodes were directly exposed to the VOC or to the water retaining VOC produced by these plant species. Furthermore, broccoli and sunflower seed were tested as biofumigants against $M$. incognita to verify the effect of VOC in combination with non-VOC. The volatilome of broccoli and sunflower seed macerates and the VOC retained in water were determined by gas chromatography (GC) and some 
purified compounds were tested both directly and in water solution against $M$. incognita.

\section{Materials and Methods}

Plant material and preparation of macerates. Broccoli (B. oleracea var. italica 'Avenger') shoots (leaves, inflorescences, and stems) and sunflower (Helianthus annuus 'Catissol') seed were collected from the horticulture and oleaginous plants sector of the Agriculture Department, Federal University of Lavras, Lavras, MG, Brazil. Sunflower seed were collected when their moisture was $18 \%$ and broccoli shoots from 90-day-old field-grown plants. Seed and shoots were stored for a maximum of $24 \mathrm{~h}$ at $7^{\circ} \mathrm{C}$ before processing. Then, $15 \mathrm{~g}$ of sunflower seed or broccoli shoots were weighed, surface sterilized by immersion in $2 \% \mathrm{NaOH}$ for $1 \mathrm{~min}$, and washed with distilled water. Each sample was immersed in $100 \mathrm{ml}$ of distilled water for $24 \mathrm{~h}$, then macerated with a kitchen blender for $20 \mathrm{~s}$ and filtered through gauze (Barros et al. 2014b). The resulting liquid was considered the aqueous macerate $(15 \mathrm{~g}$ of shoots or seed in $100 \mathrm{ml}$ of water). For the dry macerate, $15 \mathrm{~g}$ of shoots or seed were surface sterilized as described above, blotted dry, and ground with a mortar and pestle. This ground material was considered the dry macerate. Dry and aqueous broccoli shoot macerates and sunflower seed macerates were used right after preparation to obtain the VOC in subsequent experiments.

Nematode inoculum. $M$. incognita race 3 was used in all experiments. Pure populations of $M$. incognita race 3 were maintained on tomato plants (Solanum lycopersicum 'Santa Clara') in a greenhouse. The species was previously identified by esterase patterns (Carneiro et al. 2005). Eggs were obtained according to Hussey and Barker (1973). These eggs were incubated in hatching chambers at $28^{\circ} \mathrm{C}$ and only 24 -h-old second-stage juveniles $\left(\mathrm{J}_{2}\right)$ were used in the experiments.

Mortality and infectivity of $M$. incognita exposed to plant VOC. These experiments were conducted according to a previously described procedure (Barros et al. 2014b). Supelco vials (40-ml vial, $29 \mathrm{~mm}$ in diameter by $82 \mathrm{~mm}$ high, with silicon screw cap; Sigma-Aldrich, St. Louis) were half filled with $25 \mathrm{~g}$ of sterilized sand and $2 \mathrm{ml}$ of distilled water. A 1.5-ml microcentrifuge tube (Eppendorf Biotech, Hamburg, Germany) was introduced midway into the sand. Aliquots of $2 \mathrm{ml}$ of aqueous or $1.5 \mathrm{~g}$ of dry macerates of either broccoli or sunflower were placed on the sand surface around the microcentrifuge tube (Supplementary Fig. S1). The vials were sealed and incubated at $25^{\circ} \mathrm{C}$ in the dark for 3 days to allow the emission and accumulation of VOC. Then, $1 \mathrm{ml}$ of a suspension containing $100 \mathrm{~J}_{2}$ of $M$. incognita was placed inside the microcentrifuge tube with a syringe and nematodes were exposed to the $\mathrm{VOC}$ at $25^{\circ} \mathrm{C}$ for $3,6,12$, 24,48 , or $72 \mathrm{~h}$. Each sampling time consisted of an independent tube that was destructively sampled. Controls consisted of $2 \mathrm{ml}$ of distilled water applied to the sand surface at each period. After each exposure period, vials were opened and the whole $\mathrm{J}_{2}$ suspension contained in the microcentrifuge tubes was transferred to enzyme-linked immunosorbent assay (ELISA) microplates (96 wells) to determine the percentage of mobile and immobile nematodes under an inverted light microscope at $\times 20$ magnification. Nematodes that remained immobile $24 \mathrm{~h}$ after removal from the microcentrifuge tubes were considered dead.

To evaluate the infectivity of $M$. incognita, $1 \mathrm{ml}$ of a suspension containing $500 \mathrm{~J}_{2}$ was exposed to VOC emitted by dry and aqueous sunflower seed macerates, as described above. Only sunflower seed were used because this species had a stronger effect on $\mathbf{J}_{2}$ mortality than broccoli. Controls consisted of $2 \mathrm{ml}$ of distilled sterilized water instead of plant macerate. After the exposure to VOC for 3, 6, 12, 24, 48 , or $72 \mathrm{~h}$, the suspensions were collected, adjusted to $4 \mathrm{ml}$ with distilled water, and equally divided with a pipette into four holes around the stems of 20-day-old susceptible Santa Clara tomato seedlings planted in Styrofoam trays with 72 cells $\left(75 \mathrm{~cm}^{3}\right)$ filled with Multiplant substrate $(60 \%$ pine bark, $15 \%$ vermiculite, and $25 \%$ humus; Terrado Paraíso, Holambra, SP, Brazil). The water content of the substrate was $60 \%$ of the field capacity $( \pm 15 \mathrm{ml} /$ cell $)$. The inoculated seedlings were transferred to a greenhouse and received irrigation and fertilization according to the technical recommendations (Terra et al. 2017). The number of galls and eggs per gram on the roots was evaluated 45 days after the inoculation. Eggs were extracted from roots according to Hussey and Barker (1973), followed by the centrifugal-flotation method (Jenkins 1964), and counted in a Peters chamber under an inverted light microscope at $\times 20$ magnification. Egg densities were expressed as number of eggs per gram of fresh root.

The mortality experiments included three types of macerates (dry, aqueous, and control), two plants (broccoli and sunflower), and six periods of time, totaling 36 treatments. The experiment to evaluate infectivity was done with sunflower seed macerates (dry, aqueous, and control) and six periods of time, each one replicated six times, totaling 18 treatments.

Greenhouse biofumigation experiments. Plastic cups $(300 \mathrm{ml})$ were filled with a mixture of different amounts of Multiplant substrate and $0,1.2,2.4,4.8$, or $9.6 \mathrm{~g}$ of dry broccoli or sunflower seed macerate, which represented $0,1,2,4$, and $8 \%$ of the total volume of each cup. The water content of the soil was set at $60 \%$ of the field capacity in each cup ( $\pm 40 \mathrm{ml}$ ). After that, $5 \mathrm{ml}$ of a suspension containing 5,000 M. incognita eggs was added and the contents were mixed.

To test the effect of the VOC emitted by the macerates incorporated in the substrate on $M$. incognita $\mathrm{J}_{2}$, one microcentrifuge tube was buried halfway to the surface of the mixture and the cup was covered with polyethylene PVC film $(0.009 \mathrm{~mm}$ thick; PVC Alpfilm Protect, Alpes Ind., Goias, Brazil) to prevent the escape of VOC. Three days later, $1 \mathrm{ml}$ of a suspension containing $100 \mathrm{M}$. incognita $\mathrm{J}_{2}$ was injected inside each microcentrifuge tube through the PVC film with a syringe. The perforation was sealed with adhesive tape to retain the VOC and, $48 \mathrm{~h}$ later, the contents of the microcentrifuge tubes were transferred to ELISA microplates to evaluate the number of mobile, immobile, and dead $\mathrm{J}_{2}$, as described above.

After removing the PVC film and the microcentrifuge tubes, a 30day-old susceptible Santa Clara tomato seedling was transplanted to each cup containing the mixture of macerates and the $M$. incognita eggs. Seedlings were kept in a greenhouse for 45 days before evaluation of the number of galls and eggs per gram of root, as described above. The experiments consisted of broccoli and sunflower seed macerates at five concentrations each, totaling 10 treatments, and were replicated six times.

Effect of water exposed to VOC on M. incognita. Three experiments were conducted to study the effects of exposed water to broccoli VOC. In one experiment, sterile distilled water was exposed to VOC produced by dry broccoli and sunflower seed macerates in polystyrene Petri plates ( 90 by $15 \mathrm{~mm}$; Kasvi, São José do Pinhais, PR, Brazil) with two compartments (Barros et al. 2014b; Fernando et al. 2005). Dry broccoli or sunflower seed macerate $(5 \mathrm{~g})$ was placed in one compartment and water $(1 \mathrm{ml})$ was placed in the other compartment. Plates were closed, sealed with PVC film, and incubated at $25^{\circ} \mathrm{C}$ for 3 days. Controls were distilled sterile water rather than plant macerates. The water exposed to the VOC and the control were removed from the plates and placed in 2-ml microcentrifuge tubes along with $0.5 \mathrm{ml}$ of a suspension containing $100 \mathrm{M}$. incognita $\mathrm{J}_{2}$. The microcentrifuge tubes were closed and incubated at $25^{\circ} \mathrm{C}$ for $48 \mathrm{~h}$ and the numbers of motile, immobile, and dead $\mathrm{J}_{2}$ were counted. The experiment had three treatments (broccoli, sunflower, and control) and treatments were replicated six times.

In a second experiment, $\mathrm{J}_{2}$ were exposed for different durations to the water containing VOC produced by dry broccoli shoot macerate in polystyrene plates. For this, $5 \mathrm{~g}$ of dry broccoli shoot macerate was placed in one compartment of the plate and $1 \mathrm{ml}$ of sterile distilled water was placed in the other compartment. The plates were sealed with plastic film and incubated at $25^{\circ} \mathrm{C}$ for $6,12,24,48$, and $72 \mathrm{~h}$. Controls were plates containing only water in one compartment for the same periods of exposure. At the end of each period, the water was transferred to 2-ml microcentrifuge tubes along with a suspension of $0.5 \mathrm{ml}$ containing $100 \mathrm{M}$. incognita $\mathrm{J}_{2}$. The tubes were closed and incubated at $25^{\circ} \mathrm{C}$ for $48 \mathrm{~h}$, after which the number of mobile, immobile, and dead $\mathbf{J}_{2}$ was counted. Sunflower-exposed water was 
excluded from the subsequent experiments because it was not toxic to $M$. incognita. The experiment had two treatments (water and broccoli) with six exposure times per treatment and was replicated six times.

The infectivity and reproduction of $\mathrm{J}_{2}$ in water exposed to broccoli VOC for 1 and 3 days were studied as described by Terra et al. (2017) in a third experiment. Thirty-day-old Santa Clara tomato seedlings grown in Styrofoam trays with 72 cells $\left(75 \mathrm{~cm}^{3}\right)$ filled with Multiplant substrate were inoculated with $300 \mathrm{~J}_{2}$ in a 2-ml suspension. The $\mathrm{J}_{2}$ were equally distributed in four $1-\mathrm{ml}$ pipette tips $(0.5 \mathrm{ml} / \mathrm{tip})$ halfway buried into the substrate around the stems of the seedlings. Subsequently, $4 \mathrm{ml}$ of water exposed to VOC was applied to these pipette tips ( $1 \mathrm{ml} / \mathrm{tip}$ ) and, $24 \mathrm{~h}$ later, an additional $4 \mathrm{ml}$ of water exposed to VOC was added to the same pipette tips. The same volume of distilled water was used as the control treatment. Plants were kept in the greenhouse and the number of galls and eggs per gram of roots was quantified 40 days after the inoculation. Eggs were extracted according to Hussey and Barker (1973) and counted with a light microscope in a Peter's chamber. This experiment had three treatments ( 1 and 3 days of exposure and control) and was replicated six times.

Volatilome analyses by solid-phase microextraction GC mass spectrometry. The extraction of VOC was performed by placing
$1.5 \mathrm{~g}$ of dry or $5 \mathrm{ml}$ of aqueous macerate of broccoli shoots or sunflower seed in Supelco vials. Additionally, $5 \mathrm{ml}$ of water exposed for $72 \mathrm{~h}$ to VOC emitted by broccoli shoot macerate and sunflower seed macerate was also used for VOC extraction in 20-ml Supelco vials. The extraction of VOC from the samples in the Supelco vials (dry and aqueous macerates and the exposed water of each plant species) was performed using HeadSpace solid-phase microextraction (SPME) (Arthur and Pawliszyn 1990) with the following parameters: fiber divinylbenzene, carboxen, and polydimethylsiloxane; extraction temperature of $55^{\circ} \mathrm{C}$ and sample agitation at $250 \mathrm{rpm}$; and extraction time of $35 \mathrm{~min}$ and desorption time in the GC injector of $2 \mathrm{~min}$. For separation and identification of VOC, a gas chromatographer coupled to a GC mass spectrometry QP 2010 Ultra mass spectrometer (Shimadzu, Kyoto, Japan), equipped with an AOC-5000 automated injector for liquids and gases (Shimadzu) and an HP-5 column $(30 \mathrm{~m}$ by $0.25 \mathrm{~mm}$ by $0.25 \mu \mathrm{m}, 5 \%$ phenyl and $95 \%$ dimethylsiloxane), was used. Temperatures were $250^{\circ} \mathrm{C}$ for the injector, $240^{\circ} \mathrm{C}$ for the interphase, and $200^{\circ} \mathrm{C}$ for the ion source of the detector. The injector was operated in splitless mode or in split 1:4 mode, according to the intensity of the peaks in the samples. Helium grade 5.0 at $1 \mathrm{ml} / \mathrm{min}$ was used as a carrier gas. The temperature programming in the $\mathrm{GC}$ oven was set from 40 to $160^{\circ} \mathrm{C}$ at $3^{\circ} \mathrm{C} / \mathrm{min}$ and then to $240^{\circ} \mathrm{C}$ at $10^{\circ} \mathrm{C} / \mathrm{min}$. The mass spectrometer was operated in scanning
A
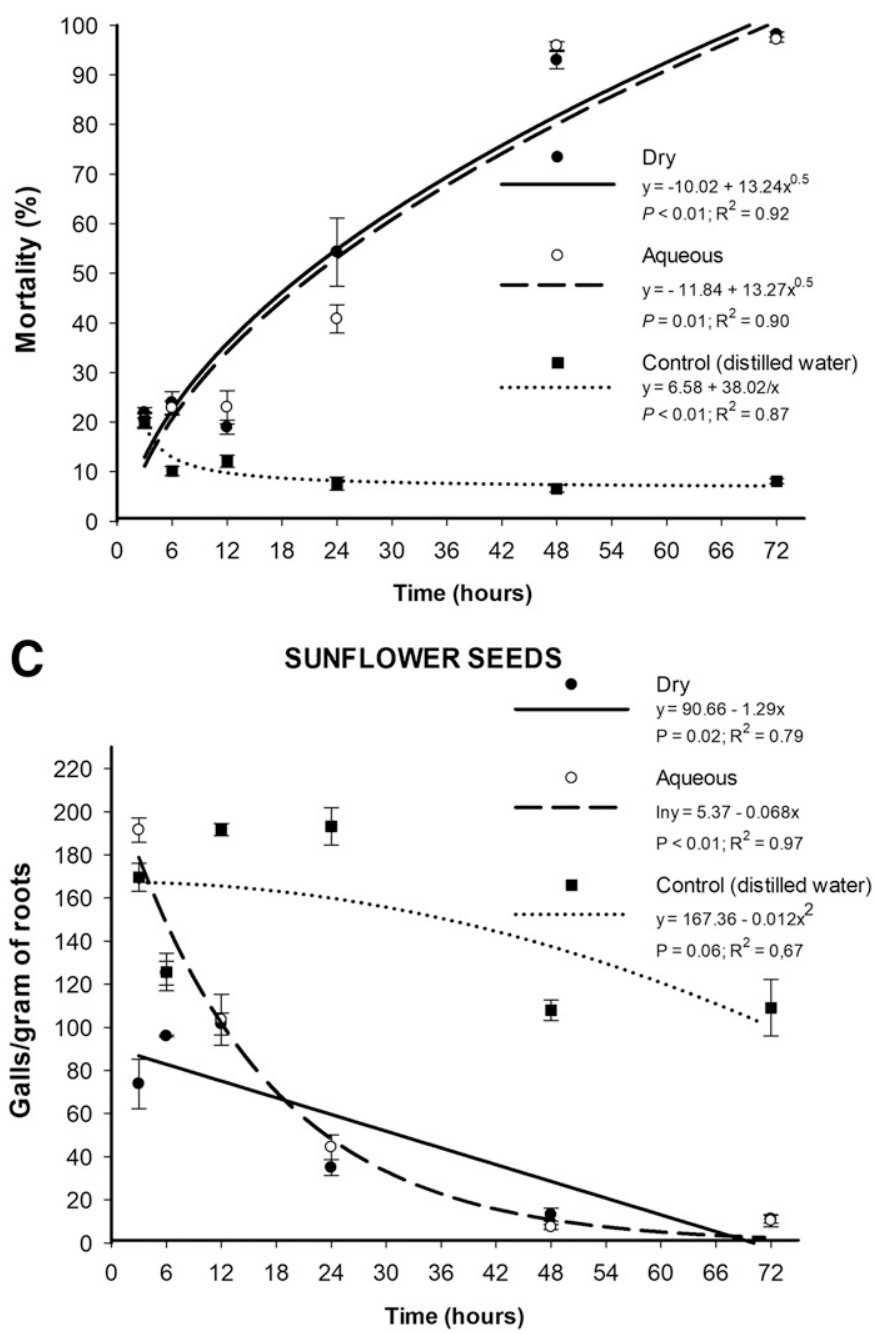

B

\section{BROCCOLI SHOOTS}
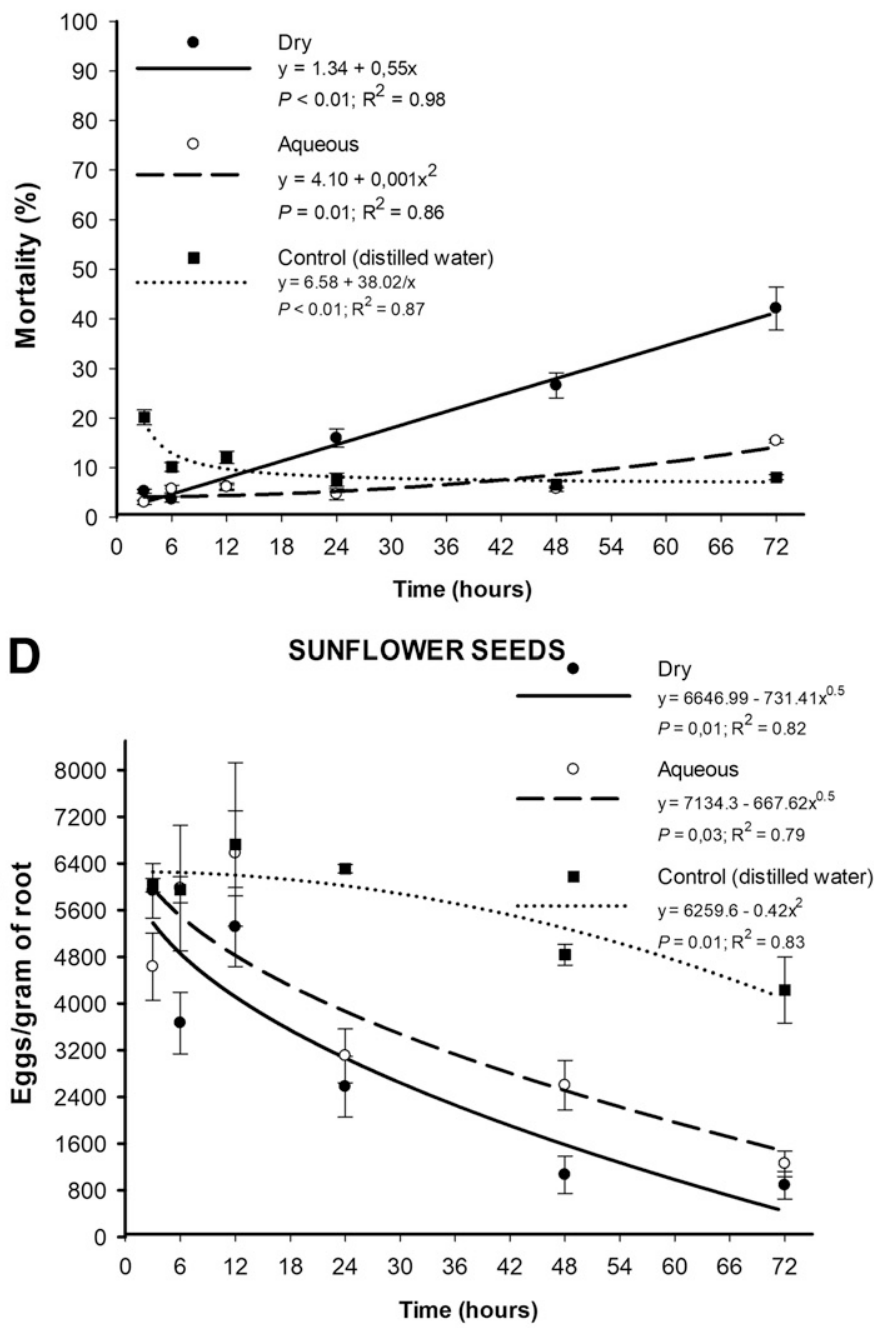

Fig. 1. Effects of volatile organic compounds (VOC) from plant macerates on Meloidogyne incognita in relation to the time of exposure. A, In vitro evaluation of VOC from dry and aqueous macerates from sunflower seed in the mortality of $M$. incognita second-stage juveniles $\left(\mathrm{J}_{2}\right)$. B, In vitro evaluation of VOC from dry and aqueous macerates from broccoli shoots in the mortality of $M$. incognita $\mathrm{J}_{2}$. C, Number of galls and $\mathbf{D}$, number of eggs in tomato roots produced by $\mathrm{J}_{2}$ exposed to VOC from dry and aqueous macerates of sunflower seed. Number of galls and eggs determined 45 days after the inoculation of $500 \mathrm{~J}_{2}$ on tomato roots (Solanum lycopersicum 'Santa Clara'). Controls were the $\mathrm{J}_{2}$ exposed to distilled water. Error bars represent the standard error of the means. 
mode in the range of 40 to 350 atomic mass units. To identify VOC in the plant samples, the mass spectra of each peak of the chromatogram were extracted through the software Automated Mass Spectral Deconvolution and Identification System, v. 2.63. The identification of VOC was performed by comparing the mass spectra of the sample peaks with spectra from the National Institute of Standards and Technology (NIST) library using the software Mass Spectral Search Program (v. 1.7; NIST, Washington, DC) and by comparing the retention indexes obtained experimentally with the retention indexes found in the literature (Adams 2007; NIST 2016). Only peaks with a similarity higher than $80 \%$ between mass spectra were considered in comparisons. The experimental retention indexes were obtained through injection of a homologous series of alkanes.

Selection and activity of purified VOC. Three VOC were selected among the ones detected in the water exposed to broccoli macerates. These VOC were chosen because only water exposed to VOC from broccoli showed activity against $M$. incognita. Only VOC detected in both dry and aqueous macerates and in the water exposed to the dry macerate were chosen. Purified dimethyl sulfide (DMS; $\left(\mathrm{CH}_{3}\right)_{2} \mathrm{~S}$, anhydrous, $\geq 99.0 \%$ ), dimethyl disulfide (DMDS; $\mathrm{CH}_{3} \mathrm{SSCH}_{3}$, anhydrous, $\geq 99.0 \%)$, and 3-pentanol $\left(\left(\mathrm{C}_{2} \mathrm{H}_{5}\right)_{2} \mathrm{CHOH}\right.$, anhydrous, $\geq 99.0 \%$ ) were acquired (Sigma-Aldrich) and used in the in vitro and in vivo experiments described below.

This experiment was done in $1.5-\mathrm{ml}$ microcentrifuge tubes containing $0.5 \mathrm{ml}$ of each VOC diluted in water at different concentrations and $0.5 \mathrm{ml}$ of water with $100 \mathrm{~J}_{2}$. DMS and 3-pentanol were diluted in water containing $0.01 \%$ Tween 20 at final concentrations of $600,800,900,1,000$, and $1,100 \mathrm{ppm}(\mu \mathrm{l} / \mathrm{ml})$, whereas DMDS was diluted at $200,300,400,500$, and $700 \mathrm{ppm}(\mu \mathrm{l} / \mathrm{ml})$. These concentrations were determined on the basis of pilot tests (data not shown). Controls consisted of water with $0.01 \%$ Tween 20 without VOC $(0 \mathrm{ppm})$. The tubes were closed and incubated at $25^{\circ} \mathrm{C}$ for $48 \mathrm{~h}$ and, after that, the $\mathrm{J}_{2}$ were collected on a 500 -mesh sieve, washed with distilled water, and transferred to ELISA plates, and the number of mobile, immobile, and dead $\mathrm{J}_{2}$ was determined as described above. The experiment had six treatments and treatments were replicated six times.

In another experiment, distilled sterile water was exposed to the purified VOC. Polystyrene Petri plates ( 90 by $15 \mathrm{~mm}$; Kasvi) divided into two compartments were used in this experiment. In one compartment, $150 \mu \mathrm{l}$ of each purified VOC was applied on the surface of a sterile cellulose filter paper (1:11 $\mu \mathrm{m}$ porosity) and $1 \mathrm{ml}$ of water was placed in the other compartment. To test the mixture of the three VOC, $50 \mu \mathrm{l}$ of each was applied on three separate pieces of filter paper in the same compartment. The plates were sealed with plastic film and incubated at $25^{\circ} \mathrm{C}$ for $72 \mathrm{~h}$. Controls were plates containing only water in one compartment for the same exposure period. After incubation, the water was transferred to 2-ml microcentrifuge tubes along with a $0.5-\mathrm{ml}$ suspension containing $600 \mathrm{M}$. incognita $\mathrm{J}_{2}$. The tubes were sealed and incubated at $25^{\circ} \mathrm{C}$ for $48 \mathrm{~h}$, after which the number of mobile and immobile $\mathrm{J}_{2}$ was evaluated in $250 \mu \mathrm{l}$ of the suspension (approximately $100 \mathrm{~J}_{2}$ ). The remaining suspension (approximately $500 \mathrm{~J}_{2}$ ) was inoculated around the roots of 20-day-old tomato seedlings. The seedlings were kept in a greenhouse for 40 days after the
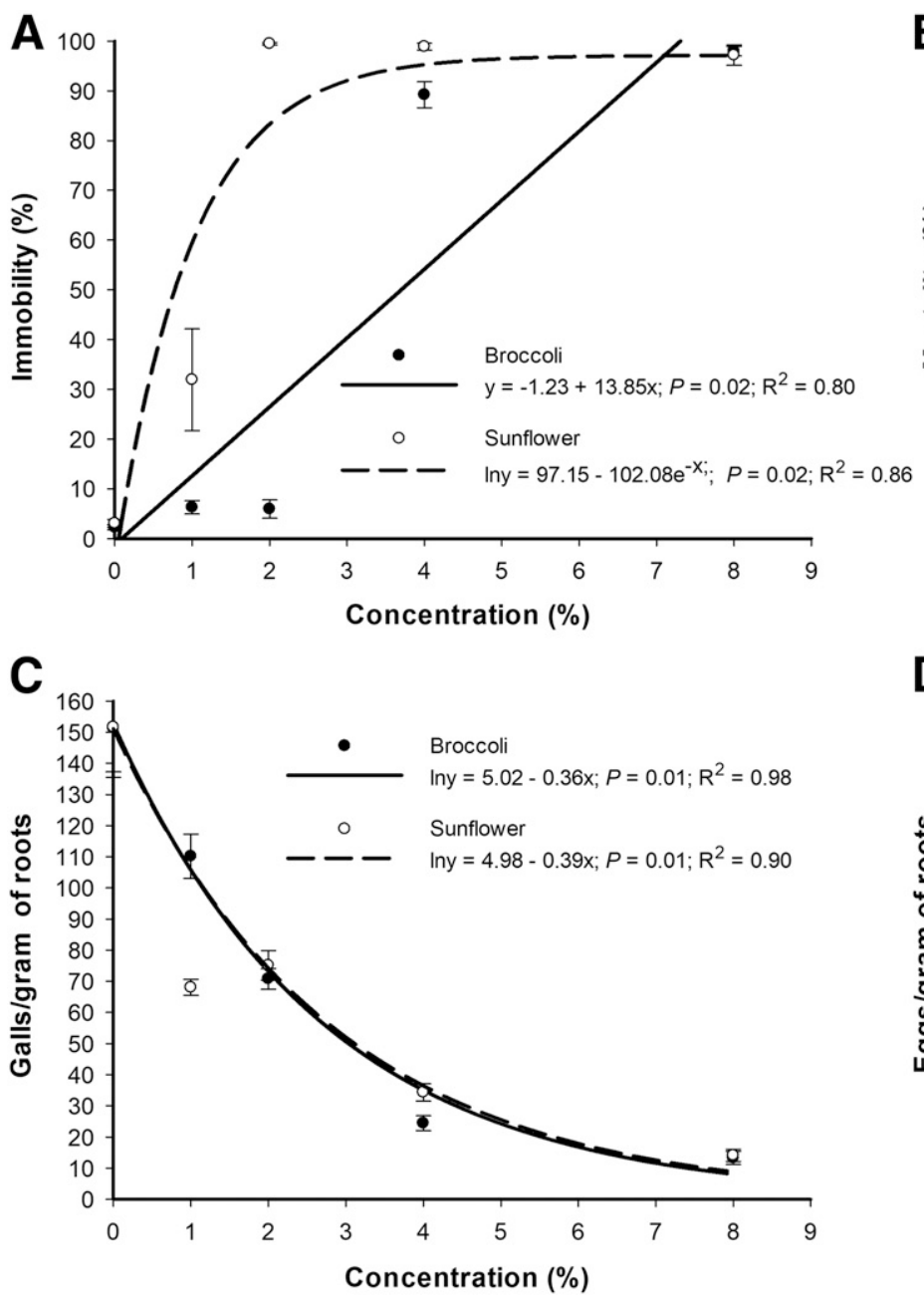
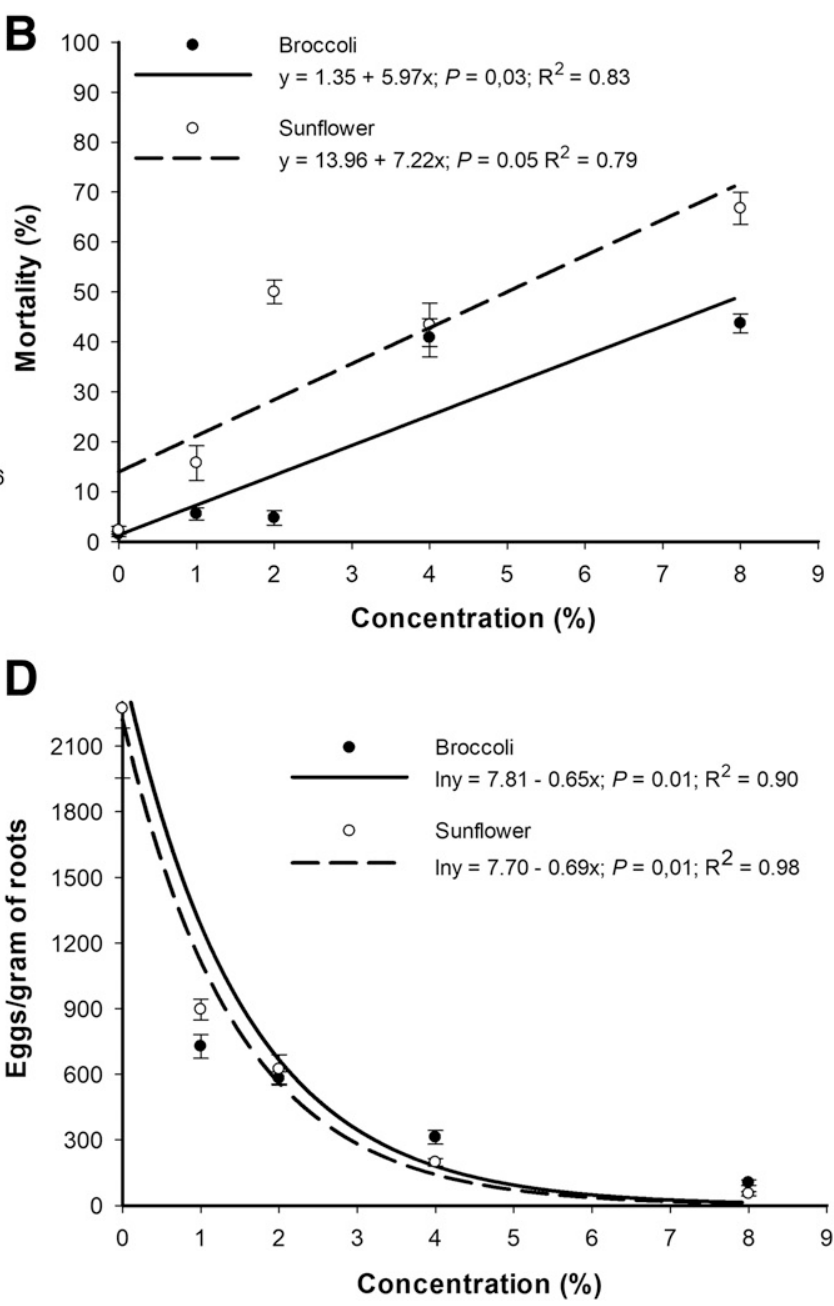

Fig. 2. Soil biofumigation with sunflower seed and broccoli shoots at different concentrations $(0,1,2,4$, and $8 \%)$ in the substrate. A, Immobility and B, mortality of Meloidogyne incognita second-stage juveniles $\left(\mathrm{J}_{2}\right)$ after exposure to volatile organic compounds from plant macerates. C, Number of galls and $\mathbf{D}$, number of eggs in tomato roots cultivated in soil infested with $500 \mathrm{~J}_{2}$ of $M$. incognita under biofumigation. After the biofumigation, a tomato seedling (Solanum lycopersicum 'Santa Clara') was transplanted to each cup and they were cultivated in the greenhouse for 45 days before the evaluations. Bars represent the standard error of the means. 
inoculation and the number of galls and eggs per gram of root was determined as described above.

Data analysis. All experiments were performed twice. No differences were observed between repeats for all experiments by analysis of variance interaction (experiment 1-experiment 2). Therefore, a combined analysis was performed for every two experiments, and the data presented are the combined results of the repeats. Then, results from all experiments were submitted to the normality test of Shapiro-Wilk and to the test of variance homogeneity of Bartlett. Analyses of variance with the $F$ test were performed after assuring that the data fit the normal distribution. For data sets with a significant $F$ test $(P<0.05)$, the mean values of different treatments were compared with the Tukey test $(P<0.05)$. The analyses were done by the statistical and graphic program Sigma-Plot, version 12.0.
Quantitative treatments such as different periods of exposure to VOC and different concentrations of plant macerates or VOC were evaluated by linear or nonlinear regression and the curves were chosen by their best fit by the program SigmaPlot, version 12.0. Lethal concentrations $\left(\mathrm{LC}_{50}\right)$ of purified compounds were calculated by Probit Analysis by the program Excel.

\section{Results}

Mortality and infectivity of $M$. incognita exposed to plant VOC. VOC produced by both dry and aqueous sunflower seed caused higher mortality of $M$. incognita $\mathrm{J}_{2}$ than $\mathrm{VOC}$ produced by broccoli shoot macerates $(P<0.01)$ (Fig. 1). The increase in the periods of exposure to VOC emitted by sunflower seed from both dry $(P<0.01)$ and aqueous macerates $(P<0.01)$ significantly increased
A

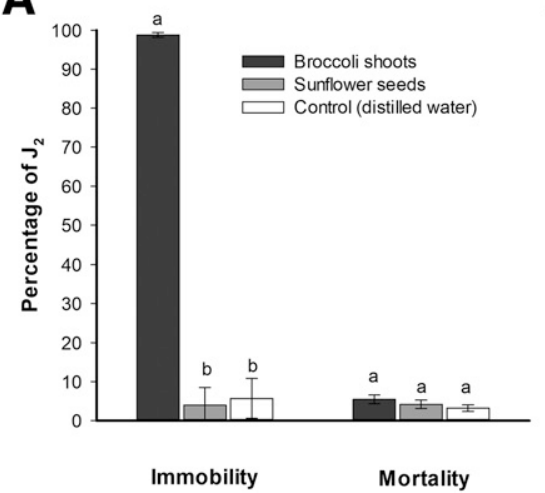

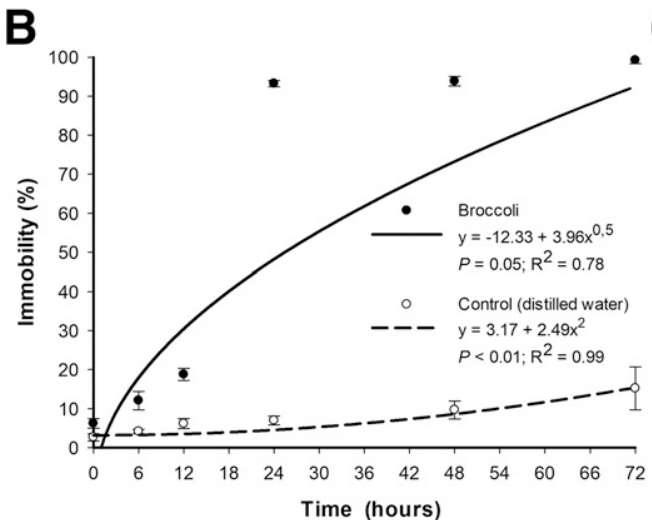

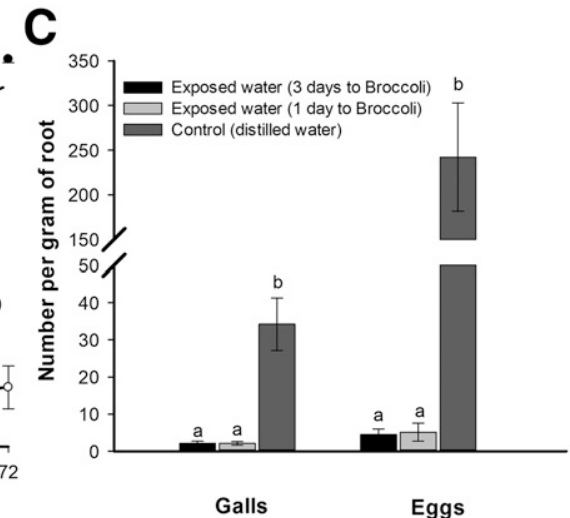

Fig. 3. Toxicity of water exposed to volatile organic compounds (VOC) from plant macerates. A, Immobility and mortality of Meloidogyne incognita second-stage juveniles $\left(\mathrm{J}_{2}\right)$ treated with water exposed to VOC from broccoli shoots and sunflower seed. B, Effect of different times of exposure of water to VOC from broccoli shoots on M. incognita $\mathrm{J}_{2}$. C, Number of galls and of eggs in tomato roots inoculated with $500 \mathrm{~J}_{2}$ treated with water exposed to broccoli VOC for 1 or 3 days. Evaluations of galls and eggs were performed 45 days after the inoculation of $500 \mathrm{~J}_{2}$ on tomato roots (Solanum lycopersicum 'Santa Clara'). Mean values followed by the same letter are not significantly different according to Tukey's test at 5\%. Error bars represent the standard error of the means.

Table 1. Volatile organic compounds identified in broccoli shoots macerates by solid-phase microextraction gas chromatography mass spectrometry ${ }^{\mathrm{a}}$

\begin{tabular}{|c|c|c|c|c|c|c|c|}
\hline & Compound & RI $\operatorname{Exp}^{b}$ & RI Litc & $\operatorname{Sim}(\%)^{d}$ & Dry macerate & Aqueous macerate & Exposed water \\
\hline \multicolumn{8}{|c|}{ Alcohol } \\
\hline 1 & Ethanol & $\ldots$ & $\ldots$ & 96 & + & $\ldots$ & + \\
\hline 2 & 3-Pentanol & 693 & 685 & 88 & + & + & + \\
\hline 3 & 3-Methyl-butanol & 730 & 734 & 92 & + & $\ldots$ & + \\
\hline 4 & 3-Hexenol (E) & 849 & 851 & 95 & ++ & $\ldots$ & + \\
\hline 5 & 3-Hexenol (Z) & 855 & 857 & 92 & ++ & $\ldots$ & + \\
\hline 6 & Hexanol & 869 & 869 & 91 & ++ & $\ldots$ & $\ldots$ \\
\hline 7 & Phenylethyl alcohol & 1,110 & 1,116 & 88 & + & $\ldots$ & $\ldots$ \\
\hline \multicolumn{8}{|c|}{ Sulfuredes } \\
\hline 1 & Metanothiol & $\ldots$ & $\ldots$ & 91 & + & + & $\ldots$ \\
\hline 2 & Dimethyl sulfide & $\ldots$ & $\ldots$ & 92 & + & + & + \\
\hline 3 & Methyl thyocianate & 709 & 711 & 91 & + & + & + \\
\hline 4 & Dimethyl disulfide & 738 & 744 & 97 & ++ & ++ & + \\
\hline 5 & Dimethyl trisulfide & 968 & 955 & 92 & ++ & + & $\ldots$ \\
\hline 6 & Dimethyl tretrasulfide & 1,211 & 1,222 & 93 & + & $\ldots$ & $\ldots$ \\
\hline \multicolumn{8}{|c|}{ Ester } \\
\hline 1 & 3-Hexenyl pentanoate (E) & 1,225 & $\ldots$ & 91 & + & $\ldots$ & $\ldots$ \\
\hline 2 & 3-Hexenyl pentanoate (Z) & 1,230 & 1,235 & 91 & + & $\ldots$ & $\ldots$ \\
\hline \multicolumn{8}{|c|}{ Aldehyde } \\
\hline 1 & 2-Heptenal & 957 & 964 & 82 & ++ & $\ldots$ & $\ldots$ \\
\hline 2 & Nonanal & 1,098 & 1,102 & 91 & + & $\ldots$ & $\ldots$ \\
\hline \multicolumn{8}{|c|}{ Ketone } \\
\hline 1 & 2-Nonanone & 1,086 & 1,091 & 91 & + & + & $\ldots$ \\
\hline \multicolumn{8}{|c|}{ Others } \\
\hline 1 & 4-Methylthio butanenitrile & 1,079 & 1,051 & 88 & + & + & $\ldots$ \\
\hline 2 & 5-Methylthio entanenitrile & 1,192 & 1,174 & 88 & ++ & ++ & $\ldots$ \\
\hline
\end{tabular}

a Symbols: + indicates presence of the molecule and ++ indicates present in a relatively higher concentration.

${ }^{\mathrm{b}}$ Calculated retention indices by injecting a homologous series of alkanes.

c Theoretical retention index according to the literature (Adams 2007).

${ }^{\mathrm{d}}$ Similarity between the peak of the mass spectrum and mass spectrum of the library. 
M. incognita $\mathrm{J}_{2}$ mortality, with $98 \%$ after $72 \mathrm{~h}$ of exposure (Fig. 1A). The same period of exposure to VOC from broccoli shoots led to a $43 \%$ mortality for the dry macerate $(P<0.01)$, whereas the aqueous macerate just differed from the control at $72 \mathrm{~h}$ of exposure $(P=0.02)$ (Fig. 1B).

Infectivity (number of galls) and reproduction (number of eggs) were only tested for the sunflower seed macerate due to its higher activity on $M$. incognita $\mathrm{J}_{2}$ mortality when compared with broccoli shoot macerates. The infectivity and reproduction of $M$. incognita decreased with the increment of the exposure period to sunflower seed macerates starting at $12 \mathrm{~h}$ of exposure $(P<0.01)$ and was similar for both dry and aqueous macerates. Reproduction was reduced by more than $80 \%$ and infectivity was reduced by $95 \%$ after $72 \mathrm{~h}$ of exposure (Fig. 1C and D).

Biofumigation with plant macerate against $M$. incognita in plastic cups. The immobility and mortality of $M$. incognita $\mathrm{J}_{2}$ were higher when the nematode was exposed to VOC from sunflower seed macerates than to VOC from broccoli macerates $(P<0.01)$ (Fig. $2 \mathrm{~A}$ and B). VOC produced by the substrate mixed with sunflower seed macerates caused almost $100 \%$ immobility at a concentration of $2 \%$, whereas VOC from broccoli shoot macerates showed a similar effect only at $4 \%$ (Fig. 2A). The mortality of $\mathrm{J}_{2}$ exposed to $8 \%$ of broccoli and sunflower seed macerates mixed with the substrate was 46 and 64\%, respectively (Fig. 2B).

Although there were differences in mobility and mortality of $\mathrm{J}_{2}$ exposed to VOC (Fig. 1A and B), there were no significant differences between broccoli and sunflower seed macerates on the number of galls $(P=0.62)$ or on the number of eggs $(P=0.90)$ produced by $M$. incognita when the initial inoculum was eggs in direct contact with the biofumigated substrate (Fig. 2C and D). Broccoli and sunflower seed macerates incorporated into the substrate significantly reduced infectivity $(P<0.01)$ and reproduction $(P<0.01)$ of $M$. incognita in tomato roots, starting at $1 \%$ of macerate. At a concentration of $8 \%$ for both broccoli and sunflower, the number of galls and eggs per gram of roots was reduced by 89 and $95 \%$, respectively, when compared with the $0 \%$ control (Fig. $2 \mathrm{C}$ and D).

Table 2. Volatile organic compounds identified in sunflower seed macerates by solid-phase microextraction gas chromatography mass spectrometry ${ }^{\mathrm{a}}$

\begin{tabular}{|c|c|c|c|c|c|c|c|}
\hline & Compound & RI $\operatorname{Exp}^{b}$ & RI Lit Lit $^{c}$ & $\operatorname{Sim}(\%)^{d}$ & Dry macerate & Aqueous macerate & Exposed water \\
\hline \multicolumn{8}{|c|}{ Alcohol } \\
\hline 1 & Ethanol & $\ldots$ & $\ldots$ & 98 & ++ & $\ldots$ & + \\
\hline 2 & 3-Methyl-butanol & 732 & 734 & 96 & + & ++ & + \\
\hline 3 & 2-Methyl-butanol & 736 & 738 & 92 & + & $\ldots$ & + \\
\hline 4 & 2,3-Butanediol & 819 & $\ldots$ & 96 & + & ++ & $\ldots$ \\
\hline 5 & 1-Hexanol & 869 & 869 & 92 & + & + & + \\
\hline 6 & 2-Heptanol & 904 & 905 & 94 & $\ldots$ & ++ & $\ldots$ \\
\hline 7 & 2-Ethyl-hexanol & 1,030 & 1,029 & 88 & $\ldots$ & + & + \\
\hline 8 & 2-Nonenol & 1,097 & 1,097 & 88 & $\ldots$ & ++ & $\ldots$ \\
\hline 9 & 2-Undecanol & 1,297 & 1,301 & 88 & $\ldots$ & + & $\ldots$ \\
\hline \multicolumn{8}{|c|}{ Terpenes } \\
\hline 1 & $\alpha$-Thujene & 924 & 924 & 92 & + & $\ldots$ & $\ldots$ \\
\hline 2 & $\alpha$-Pinene & 932 & 932 & 94 & ++ & + & $\ldots$ \\
\hline 3 & Thuja-2,4(10)diene & 952 & 953 & 80 & $\ldots$ & + & ++ \\
\hline 4 & Sabinene & 972 & 969 & 81 & + & $\ldots$ & $\ldots$ \\
\hline 5 & $\beta$-Pinene & 977 & 974 & 86 & + & $\ldots$ & $\ldots$ \\
\hline 6 & $\alpha$-Terpinene & 1,016 & 1,014 & 88 & + & $\ldots$ & $\ldots$ \\
\hline 7 & Ocimene & 1,023 & 1,022 & 93 & + & $\ldots$ & $\ldots$ \\
\hline 8 & Limonene & 1,027 & 1,024 & 92 & + & $\ldots$ & $\ldots$ \\
\hline 9 & Eucalyptol & 1,030 & 1,026 & 91 & + & $\ldots$ & $\ldots$ \\
\hline 10 & $\gamma$-Terpinene & 1,054 & 1,054 & 88 & + & $\ldots$ & $\ldots$ \\
\hline 11 & Transpinocar+eol & 1,135 & 1,135 & 91 & $\ldots$ & + & $\ldots$ \\
\hline 12 & Verbenol (Z) & 1,141 & 1,137 & 88 & $\ldots$ & + & + \\
\hline 13 & Terpienol & 1,175 & 1,177 & 92 & + & + & ++ \\
\hline 14 & Mirtenol & 1,192 & 1,193 & 90 & $\ldots$ & + & + \\
\hline 15 & Verbenone & 1,203 & 1,204 & 86 & + & $\ldots$ & + \\
\hline \multicolumn{8}{|l|}{ Ester } \\
\hline 1 & s-Methyl-thiopropanoate & 797 & $\ldots$ & 81 & $\ldots$ & + & $\ldots$ \\
\hline 2 & s-Metyl thioctanoate & 1,291 & 1,293 & 91 & $\ldots$ & + & $\ldots$ \\
\hline \multicolumn{8}{|c|}{ Aldehyde } \\
\hline 1 & 3-Methyl-butanal & 649 & 654 & 89 & + & $\ldots$ & $\ldots$ \\
\hline 2 & 2-Methyl-butanal & 658 & 664 & 92 & + & $\ldots$ & $\ldots$ \\
\hline \multicolumn{8}{|c|}{ Ketones } \\
\hline 1 & 2-Pentanone & 684 & 685 & 94 & $\ldots$ & + & + \\
\hline 2 & 2,3-Heptadione & 832 & $\ldots$ & 95 & $\ldots$ & + & $\ldots$ \\
\hline 3 & 2-Heptanone & 888 & 889 & 91 & $\ldots$ & ++ & + \\
\hline 4 & 3-Octanone & 987 & 988 & 85 & $\ldots$ & ++ & $\ldots$ \\
\hline 5 & 2-Nonanone & 1,086 & 1,091 & 92 & $\ldots$ & + & $\ldots$ \\
\hline 6 & 2-Undecanone & 1,287 & 1,293 & 90 & $\ldots$ & ++ & $\ldots$ \\
\hline \multicolumn{8}{|c|}{ Phenol } \\
\hline 1 & p-Vinyl guaiacol & 1,307 & 1,309 & 92 & $\ldots$ & + & $\ldots$ \\
\hline 2 & Phenol & 993 & 992 & 95 & $\ldots$ & ++ & $\ldots$ \\
\hline \multicolumn{8}{|c|}{ Others } \\
\hline 1 & Acetic acid & 702 & $\ldots$ & 97 & + & $\ldots$ & + \\
\hline
\end{tabular}

a Symbols: + indicates the presence of the molecule and ++ indicates present in a relatively higher concentration.

${ }^{\mathrm{b}}$ Calculated retention indices by injecting a homologous series of alkanes.

c Theoretical retention index according to the literature (Adams 2007).

d Similarity between the peak of the mass spectrum and mass spectrum of the library. 
Effect of water exposed to plant VOC on M. incognita. Water exposed to VOC emitted by the macerate of broccoli shoots significantly lowered the mobility of $M$. incognita $\mathrm{J}_{2}$ by $97 \%(P<0.01)$, whereas water exposed to VOC from sunflower seed macerates did not affect the mobility of the $\mathrm{J}_{2}$. The mortality of $M$. incognita $\mathrm{J}_{2}$ exposed to VOC produced by broccoli and sunflower seed macerates was not significantly different from the control treatment $(P=$ 0.29) (Fig. 3A). Increased time of exposure to VOC produced by broccoli shoot macerates significantly decreased the mobility of M. incognita $(P<0.01)$, with approximately $100 \%$ of the $\mathrm{J}_{2}$ immobile after $24 \mathrm{~h}$ of exposure, whereas more than $83 \%$ of the $\mathrm{J}_{2}$ remained motile in the control treatment (Fig. 3B). When water exposed to broccoli VOC for 1 or 2 days was applied to the infested soil, there were $98 \%$ fewer galls $(P<0.01)$ and $98 \%$ fewer eggs $(P<0.01)$ in tomato roots than in the water control (Fig. 3C).

Volatilome of plant macerates. Sunflower seed macerates produced an overall higher number of volatile molecules than broccoli shoot macerates (Tables 1 and 2). In general, a lower number of molecules was detected in the water exposed to dry macerates than in dry and aqueous macerates of both plant species. Twenty molecules were detected in dry broccoli shoot macerates and nine and eight molecules were identified in aqueous macerate and in the water exposed to dry macerates of broccoli, respectively. On the other hand, 19, 25 , and 13 molecules were detected in dry and aqueous macerates and in water exposed to sunflower seed macerates, respectively. Sulfurated volatiles were exclusively produced by broccoli macerates, whereas terpenes, phenols, and acetic acid were only produced by sunflower seed macerates. Esters and aldehydes were present in dry macerates of broccoli, whereas ketones, alcohols, and sulfurated compounds were present in both dry and aqueous broccoli macerates. Aldehydes were only detected in dry sunflower seed macerates; esters, ketones, and phenols were found only in aqueous sunflower seed macerates and alcohols and terpenes were found in both dry and aqueous macerates of sunflower seed. As expected, all molecules detected in the water exposed to VOC were also detected in dry or aqueous broccoli or sunflower seed macerates. In water exposed to VOC emitted by broccoli macerate, only alcohols and sulfurated molecules were detected, whereas water exposed to sunflower seed macerates contained alcohols, ketones, terpenes, and acetic acid (Tables 1 and 2).

Activity of selected VOC from the broccoli volatilome. The three purified VOC used in this study were selected because they were detected only in the volatilome of broccoli, which produced VOC that were retained in water, making it toxic to nematodes, as opposed to the VOC produced by sunflower seed. There was a significant effect of both 3-pentanol and DMDS on the immobility and mortality of $M$. incognita $\mathrm{J}_{2}$ with increasing concentrations $(P<0.01)$ (Fig. 4) but not for DMS $(P=0.48)$. The concentration at which $50 \%$ of the $\mathrm{J}_{2}$ were killed by the VOC $\left(\mathrm{LC}_{50}\right)$ calculated by Probit analyses was 176 ppm (upper limit $=129$ and lower limit $=$ 240) for DMDS and 918 ppm (upper limit $=993$ and lower limit $=$ 849) for 3-pentanol.

The water exposed to DMDS, 3-pentanol, and the mixture of DMDS + 3-pentanol + DMS caused, on average, 93\% immobility and $78 \%$ mortality in $\mathrm{J}_{2}$ of $M$. incognita, higher than the control and DMS, where immobility was approximately 1 to $2 \%(P<$ 0.01 ) (Fig. 5A and B). DMS-exposed water did not affect the mobility and viability of $M$. incognita as compared with the control (Fig. $5)$. When the $J_{2}$ suspension along with water exposed to DMDS, 3-pentanol, or the mixture of the three VOC was applied on the soil, there was a reduction in the number of galls and eggs that averaged 65 and $93.8 \%$, respectively $(P<0.01)$. In general, DMDS had a stronger activity than 3-pentanol, because DMDS resulted in higher $\mathrm{J}_{2}$ mortality $(P<0.01)$ (Fig. 5B) and a stronger reduction in the number of eggs $(P<0.01)$ (Fig. $5 \mathrm{C}$ and $\mathrm{D})$.

\section{Discussion}

Broccoli shoot and sunflower seed macerates produced VOC that increased the mortality and decreased mobility, infectivity, and reproduction of $M$. incognita. In general, dry macerates were more effective in killing $M$. incognita, particularly in the case of broccoli. However, dry and aqueous macerates of sunflower seed were equally effective in decreasing infectivity and reproduction of this nematode (Fig. 1). The water in the aqueous macerates may be responsible for retaining the VOC produced by broccoli and, consequently, for the lower emission of VOC from this type of macerate.

Even though sunflower seed macerates were more efficacious than broccoli macerates in decreasing mobility and increasing mortality of $\mathrm{J}_{2}$ in biofumigation experiments (Fig. 2), only the water exposed to broccoli showed activity against $M$. incognita (Fig. 3). The water does not retain the VOC that make the sunflower seed macerates toxic to nematodes but does retain some of the VOC from broccoli macerates that were originally less toxic than sunflower seed macerates (Fig. 4). Alcohols and sulfurated VOC are responsible for the toxicity of the water exposed to broccoli macerates. The toxic VOC from sunflower seed were not retained in the water. The retention of the VOC in water depends on many parameters such as boiling point, polarity, and their concentration in the gas phase. However,
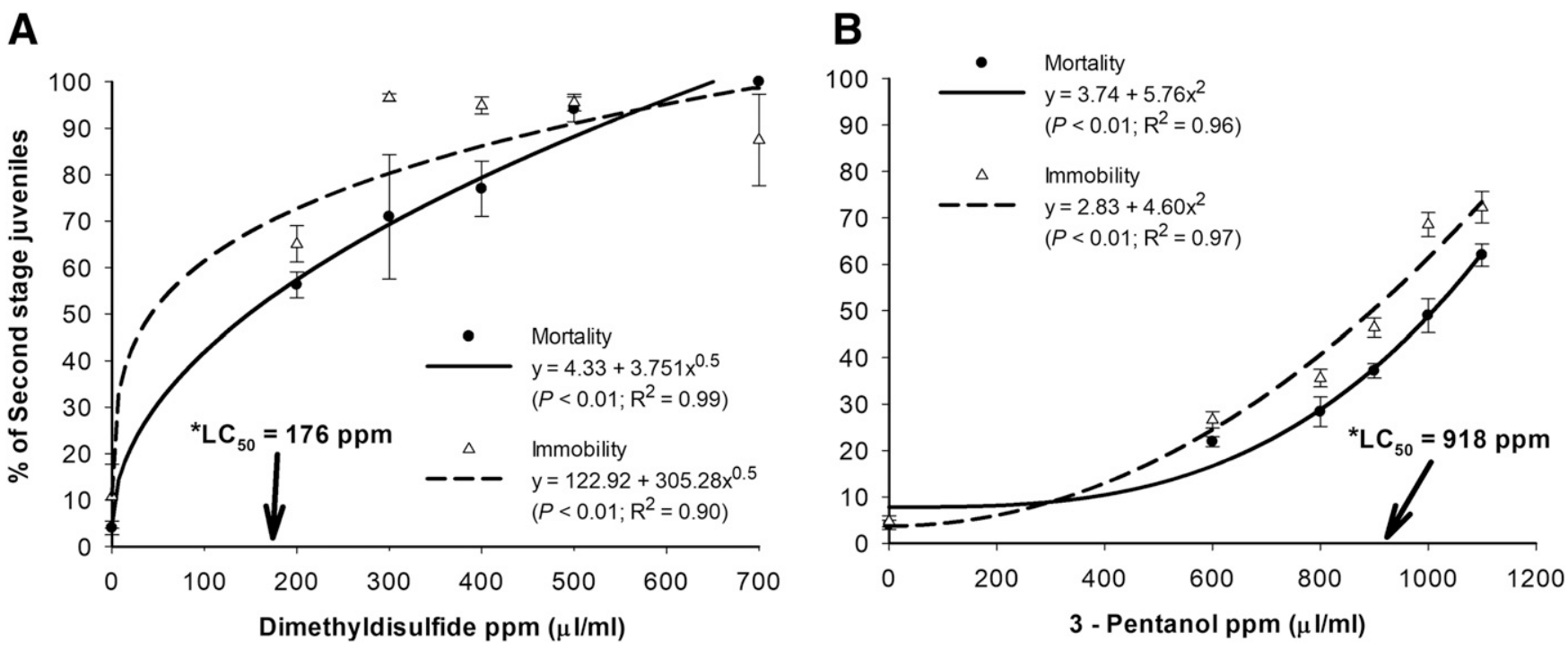

Fig. 4. Purified volatile organic compounds (VOC) from the broccoli shoot volatilome against Meloidogyne incognita second-stage juveniles $\left(\mathrm{J}_{2}\right)$. A, Immobility and mortality of $\mathrm{J}_{2}$ exposed to dimethyl disulfide at different concentrations. B, Immobility and mortality of $\mathrm{J}_{2}$ exposed to different concentrations of 3-pentanol. The $\mathrm{J}_{2}$ were exposed to the different concentrations of the VOC for $48 \mathrm{~h}$ before the evaluations. Error bars represent the standard error of the means. $\mathrm{LC}_{50}$ indicates lethal concentration required to kill $50 \%$ of the $\mathrm{J}_{2}$ calculated by Probit analysis. 
as can be observed in Table 2, with the exception of thuja-2,4(10) diene, all compounds retained in water present an $\mathrm{OH}$ or $\mathrm{CO}$ in their chemical structures, which can promote hydrogen bonding with water molecules (Tainter et al. 2012) and, therefore, increase retention in the exposed water. Consequently, all VOC from sunflower seed that are retained in water may be classified as nontoxic to M. incognita.

The significant reduction in infectivity and reproduction observed in $M$. incognita $\mathrm{J}_{2}$ exposed to VOC produced by sunflower, broccoli, and the water exposed to broccoli may be due to paralysis of the $\mathbf{J}_{2}$ rather than to their mortality (Figs. 2 and 3). VOC produced by plants usually do not cause high mortality but often are responsible for immobilizing the $M$. incognita $\mathrm{J}_{2}$, which would explain the low infectivity and reproduction in tomato roots. This confirms our previous results with VOC from macerates of mustard and neem leaves against M. incognita (Barros et al. 2014a,b). Apparently, toxic VOC may affect the nervous system of the nematodes, which disturbs the ability of the $\mathrm{J}_{2}$ to locate the host or develop feeding sites (Baillie and Wright 1985; Gentry et al. 2013).

The biofumigation experiments indicated that VOC may act alone or synergistically with non-VOC to reduce the viability of $M$. incognita, which also has been observed by other authors working on diverse green residues (Bailey and Lazarovits 2003; Estupiñan-López et al. 2017; Lord et al. 2011; Neves et al. 2007; Ploeg 2008; Ploeg and Stapleton 2001; Roubtsova et al. 2007; Wen et al. 2013). Biofumigation is traditionally performed with Brassica spp., which produce VOC and non-VOC with toxic effect against plant-parasitic nematodes (Aissani et al. 2015; Al-Rehiayani et al. 1999; Neves et al. 2007; Ngala et al. 2015; Roubtsova et al. 2007). However, despite the fact that sunflower seed non-VOC has already presented nematicidal or fungicidal activities (Ganaie et al. 2011; Giudici et al. 2000; Regente and De La Canal 2000), our study showed that sunflower is also able to produce VOC toxic to $M$. incognita and has the potential to be used in biofumigation.

VOC produced by broccoli macerates turned the water toxic to $M$. incognita in less than $24 \mathrm{~h}$ of exposure. In previous studies (Barros et al. 2014b; Grimme et al. 2007; Silva et al. 2017; Terra et al. 2017, 2018), the minimum exposure time to turn the water toxic to nematodes was not determined with precision. Due to their ability to become trapped in water, VOC generated during biofumigation may be employed in combination with irrigation practices to control nematodes. VOC retained in water are possibly active at long
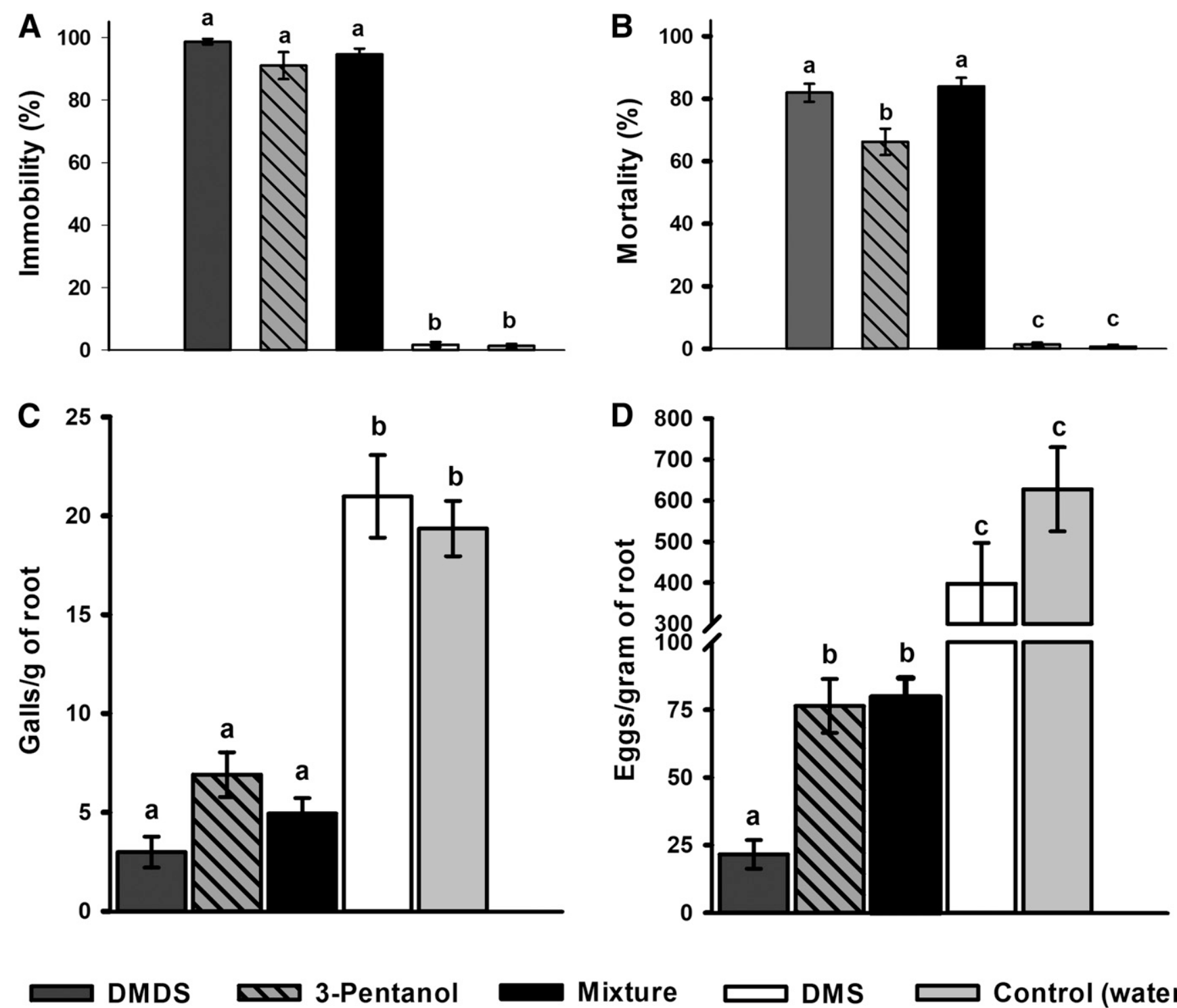

Mixture

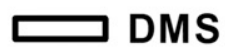

Control (water)

Fig. 5. Effect of water exposed to purified volatile organic compounds (VOC) from the broccoli shoot volatilome on Meloidogyne incognita. A, Immobility and B, mortality of secondstage juveniles $\left(\mathrm{J}_{2}\right)$ treated with water exposed to $150 \mu$ l of purified VOC or to a mixture of VOC containing $50 \mu \mathrm{l}$ of each. $\mathbf{C}$, Number of galls and D, number of eggs in tomato root inoculated with $\mathrm{J}_{2}$ treated with water exposed to $150 \mu \mathrm{l}$ of purified VOC or to a mixture of $50 \mu$ l of each VOC. Numbers of galls and eggs were determined 45 days after the inoculation of $500 \mathrm{~J}_{2}$ on tomato roots (Solanum lycopersicum 'Santa Clara'). DMDS = dimethyl disulfide, DMS = dimethyl sulfide, and Mixture = DMS + DMDS + 3-pentanol. Means followed by the same letter are not significantly different according to Tukey's test at $5 \%$ probability. Error bars represent the standard error of the means. 
distances from their site of release. Water is able to penetrate the soil pores (Wheatley 2002) and the VOC retained in it may turn the soil solution toxic to nematodes. It would be interesting to perform studies to determine the distance from the point of release and the length of time that the water remain toxic to nematodes, because VOC will eventually dissipate from the solution.

Although we are still not certain about the identity of all compounds responsible for the significant activity of broccoli shoot macerates and the exposed water to $M$. incognita, sulfurous compounds are certainly involved. Sulfurous compounds such as isothiocyanates are known nematicides produced during biofumigation with Brassica spp. (Lord et al. 2011). However, the toxicity of Brassica spp. against nematodes involves diverse molecules (Vervoort et al. 2014). DMDS and methyl thiocyanate are sulfurous compounds identified in the water exposed to broccoli macerates and were previously reported to control plant-parasitic nematodes (Zasada and Ferris 2003). DMDS is a commercial molecule (Paladin EC; Arkema Inc., Comlombes, France) already used to control $M$. incognita (Kokalis-Burelle et al. 2016). A third sulfurous volatile, DMS, also identified in the water exposed to broccoli macerates, did not show any activity against $M$. incognita even at the highest concentration tested $(1,100 \mathrm{ppm})$. These observations combined with the results of the purified compounds (Fig. 3) confirm that DMDS and methyl thiocyanate are involved in the toxicity of broccoli to $M$. incognita in soil biofumigation or when its VOC are retained in water. Purified methyl thiocyanate was not tested in our study but it appears to be more toxic to $M$. incognita than DMDS, with a reported $\mathrm{LC}_{50}$ of $18 \mathrm{ppm}$ (Aissani et al. 2015), as compared with $176 \mathrm{ppm}$ for DMDS (this study). The $\mathrm{LC}_{50}$ of these compounds is close to that of the commercial nematicide Carbofuran, which is 191 ppm (Terra et al. 2018), making methyl thiocyanate a potential compound for commercial development and field application as DMDS.

Some alcohols found in the volatilome of broccoli and sunflower seed have been shown to be toxic against plant pathogens (Barros et al. 2014b; Fialho et al. 2010; Silva et al. 2017). Among these, 3-pentanol was retained in water immobilizing and killing the $M$. in$\operatorname{cognita} \mathrm{J}_{2}$ but only at high concentrations $\left(\mathrm{LC}_{50}=918 \mathrm{ppm}\right)$. No synergistic effect was observed when the three purified compounds (DMS + DMDS + 3-pentanol) were applied together. However, some plant VOC act in concert to inhibit Meloidogyne spp. (Ntalli et al. 2011; Silva et al. 2013). Compounds such as 2,3-butanediol, sabinene, eucalyptol, limonene, and $\alpha$-thujene found in sunflower seed emission were also reported in other volatilomes with activity against M. incognita (Barros et al. 2014b; Gonçalves et al. 2016; Silva et al. 2013) but were not retained in the water.

Broccoli shoots and sunflower seed have a great potential to be used in biofumigation against Meloidogyne spp. and should be more exploited as intercrops, companion crops, or green manures for field application. Although broccoli and sunflower are not hosts for $M$. incognita, broccoli hosts other root-knot nematode species (Ciancio and Mukerji 2008). To avoid the build-up of these species on broccoli, one possible strategy would be to grow broccoli during the cooler seasons when nematode activity is limited and reproduction is slow (Ploeg 2008). Another interesting application of these plant species could be in soil incorporation combined with irrigation and soil tillage (Dutra and Campos 2003). The humidity of irrigation would stimulate the eggs to hatch and the absence of host plants combined with soil tillage would make the $J_{2}$ deplete their energy reserves without finding a suitable host. Additionally, these conditions combined with the toxic effects of the VOC released from the incorporated plants may further decrease the viability of the nematode.

Despite the fact that the plant parts used in this study are the commercial products of these crops, a small portion of the production could be used as green manure once a volume of approximately 2 to $4 \%$ (wt/wt) was enough to significantly reduce nematode infection and reproduction. A generally recommended amount for plant incorporation as biofumigant is $50 \mathrm{t} / \mathrm{ha}$ (about $2.5 \%$ ), although the efficacy of materials can vary depending on the soil and plant properties and the method of application (Bello et al. 2002; Ploeg 2008). Similar amounts of Brassica spp. have been used under field conditions in biofumigation to control the root-knot nematode $M$. chitwoodi in potato production (Mojtahedi et al. 1993). In large production fields, this volume is unfeasible for commercial parts of the plant; however, in small horticulture areas or greenhouses, this amount may be smaller than the residue that remains in the area or is discarded due to its low quality for commercial use. Particularly in the case of broccoli, approximately 6 to $10 \%$ of the shoots are discarded in small farms (Bekhit et al. 2013; Gustavsson and Stage 2011). Thus, biofumigation has shown to be more efficient in small production areas (Ploeg 2008) and the application of these crop residues in such areas may be feasible as biofumigants.

In summary, we showed that VOC from both broccoli shoots and sunflower seed have nematicidal activity against $M$. incognita in vitro and in biofumigation along with non-VOC. Therefore, these VOC should be more exploited as nematicidal compounds. VOC from both plant species were equally effective in decreasing infectivity and reproduction of the nematode but only the water exposed to broccoli macerates was toxic to $M$. incognita. Furthermore, the compounds DMDS and 3-pentanol are toxic to $M$. incognita with $\mathrm{LC}_{50}$ of 176 and 918 ppm, respectively, and can be retained in exposed water, showing their potential to be used as nematicidal compounds.

\section{Literature Cited}

Abad, P., Gouzy, J., Aury, J.-M., Castagnone-Sereno, P., Danchin, E. G., Deleury, E., Perfus-Barbeoch, L., Anthouard, V., Artiguenave, F., and Blok, V. C. 2008 Genome sequence of the metazoan plant-parasitic nematode Meloidogyne incognita. Nat. Biotechnol. 26:909-915.

Adams, R. P. 2007. Identification of Essential Oil Components by Gas Chromatography/Mass Spectrometry, 4th ed. Allured Publishing Corporation, Carol Stream, IL.

Aissani, N., Urgeghe, P. P., Oplos, C., Saba, M., Tocco, G., Petretto, G. L., Eloh, K., Menkissoglu-Spiroudi, U., Ntalli, N., and Caboni, P. 2015. Nematicidal activity of the volatilome of Eruca sativa on Meloidogyne incognita. J. Agric. Food Chem. 63:6120-6125

Al-Rehiayani, S., Hafez, S., Thornton, M., and Sundararaj, P. 1999. InvestigationResearch: Effects of Pratylenchus neglectus, Bacillus megaterium, and oil radish or rapeseed green manure on reproductive potential of Meloidogyne chitwoodi on potato. Nematropica 29:37-49.

Arthur, C. L., and Pawliszyn, J. 1990. Solid phase microextraction with thermal desorption using fused silica optical fibers. Anal. Chem. 62:2145-2148.

Bailey, K., and Lazarovits, G. 2003. Suppressing soil-borne diseases with residue management and organic amendments. Soil Tillage Res. 72:169-180.

Baillie, A. C., and Wright, K. 1985. Biochemical pharmacology. Pages 323-356 in: Comprehensive Insect Physiology, Biochemistry and Pharmacology, Vol. 2. G. A. Kerkut and L. I. Gilbert, ed. Pergamon Press, Oxford.

Baldwin, I. T., Halitschke, R., Paschold, A., Von Dahl, C. C., and Preston, C. A 2006. Volatile signaling in plant-plant interactions:" talking trees" in the genomics era. Science 311:812-815.

Barros, A. F., Campos, V. P., da Silva, J. C. P., Lopez, L. E., da Silva, A. P., Pozza, E. A., and Pedroso, L. A. 2014a. Tempo de exposição de juvenis de segundo estádio a voláteis emitidos por macerados de nim e de mostarda e biofumigação contra Meloidogyne incognita. Nematropica 44:190-199.

Barros, A. F., Campos, V. P., da Silva, J. C. P., Pedroso, M. P., Medeiros, F. H. V., Pozza, E. A., and Reale, A. L. 2014b. Nematicidal activity of volatile organic compounds emitted by Brassica juncea, Azadirachta indica, Canavalia ensiformis, Mucuna pruriens and Cajanus cajan against Meloidogyne incognita. Appl. Soil Ecol. 80:34-43.

Bekhit, A. E. D., Lingming, K., Mason, S. L., Zhou, J., and Sedcole, J. R. 2013 Upgrading the utilization of brassica wastes: Physicochemical properties and sensory evaluation of fermented brassica stalks. Int. Food Res. J. 20:1961-1969.

Bello, A., López-Pérez, J., García-Álvarez, A., Sanz, R., and LaCasa, A. 2002. Biofumigation and nematode control in the Mediterranean region. Pages 133-149 in: Proc. Fourth Int. Congr. Nematol. Tenerife, Spain.

Caboni, P., and Ntalli, N. 2014. Botanical nematicides, recent findings. Pages 145-157 in: Biopesticides: State of the Art and Future Opportunities. ACS Publications, Washington, DC.

Carneiro, R. M. D. G., Randig, O., Almeida, M. R. A., and Gonçalves, W. 2005. Identificação e caracterização de espécies de Meloidogyne em cafeeiro nos Estados de São Paulo e Minas Gerais através dos fenótipos de esterase e SCAR-Multiplex-PCR. Nematol. Bras. 29:233-242.

Ciancio, A., and Mukerji, K. G. 2008. Integrated Management and Biocontrol of Vegetable and Grain Crops Nematodes. Springer Science \& Business Media, Berlin.

Dicke, M., and Loon, J. J. 2000. Multitrophic effects of herbivore-induced plant volatiles in an evolutionary context. Entomol. Exp. Appl. 97:237-249.

Dudareva, N., Klempien, A., Muhlemann, J. K., and Kaplan, I. 2013. Biosynthesis, function and metabolic engineering of plant volatile organic compounds. New Phytol. 198:16-32. 
Dudareva, N., Negre, F., Nagegowda, D. A., and Orlova, I. 2006. Plant volatiles: Recent advances and future perspectives. Crit. Rev. Plant Sci. 25:417-440.

Dutra, M. R., and Campos, V. P. 2003. Soil and water management as a new tactic, for controlling Meloidogyne incognita in Phaseolus vulgaris. Fitopatol. Bras. 28:1-7.

Estupiñan-López, L., Campos, V. P., Silva, A. P., Barros, A. F., Pedroso, M. P., Silva, J. C., and Terra, W. C. 2017. Volatile organic compounds from cottonseed meal are toxic to Meloidogyne incognita. Trop. Plant Pathol. 42: 443-450.

Fernando, W. D., Ramarathnam, R., Krishnamoorthy, A. S., and Savchuk, S. C. 2005. Identification and use of potential bacterial organic antifungal volatiles in biocontrol. Soil Biol. Biochem. 37:955-964.

Fialho, M. B., Toffano, L., Pedroso, M. P., Augusto, F., and Pascholati, S. F. 2010. Volatile organic compounds produced by Saccharomyces cerevisiae inhibit the in vitro development of Guignardia citricarpa, the causal agent of citrus black spot. World J. Microbiol. Biotechnol. 26:925-932.

Ganaie, M. A., Rather, A. A., and Siddiqui, M. A. 2011. Pathogenicity of root knot nematode Meloidogyne incognita on okra and its management through botanicals. Arch. Phytopathol. Plant Prot. 44:1683-1688.

Gentry, K. R., Steele, L. M., Sedensky, M. M., and Morgan, P. G. 2013. Early developmental exposure to volatile anesthetics causes behavioral defects in Caenorhabditis elegans. Anesth. Analg. 116:185-189.

Giudici, A. M., Regente, M. C., and de la Canal, L. 2000. A potent antifungal protein from Helianthus annuus flowers is a trypsin inhibitor. Plant Physiol. Biochem. 38:881-888.

Gonçalves, F. J. T., Barbosa, F. G., Lima, J. S., Coutinho, I. B. L., Oliveira, F. C., Rocha, R. R., and Andrade Neto, M. 2016. Atividade antagonista do óleo essencial de Lippia alba (Mill.) N. E. Brown (Verbenaceae) sobre Meloidogyne incognita (Kofoid \& White) Chitwood [Antagonist activity of the essential oil Lippia alba (Mill.) N. E. Brown (Verbenaceae) on Meloidogyne incognita (Kofoid \& White) Chitwood]. Rev. Bras. Plant. Med. 18:149-156.

Grimme, E., Zidack, N., Sikora, R., Strobel, G., and Jacobsen, B. 2007. Comparison of Muscodor albus volatiles with a biorational mixture for control of seedling diseases of sugar beet and root-knot nematode on tomato. Plant Dis. 91:220-225.

Gu, Y.-Q., Mo, M.-H., Zhou, J.-P., Zou, C.-S., and Zhang, K.-Q. 2007. Evaluation and identification of potential organic nematicidal volatiles from soil bacteria. Soil Biol. Biochem. 39:2567-2575.

Gustavsson, J., and Stage, J. 2011. Retail waste of horticultural products in Sweden. Resour. Conserv. Recycling 55:554-556.

Heil, M., and Ton, J. 2008. Long-distance signalling in plant defence. Trends Plant Sci. 13:264-272

Henderson, D. R., Riga, E., Ramirez, R. A., Wilson, J., and Snyder, W. E. 2009. Mustard biofumigation disrupts biological control by Steinernema spp. nematodes in the soil. Biol. Control 48:316-322.

Huang, Y., Xu, C., Ma, L., Zhang, K., Duan, C., and Mo, M. 2010. Characterisation of volatiles produced from Bacillus megaterium YFM3. 25 and their nematicidal activity against Meloidogyne incognita. Eur. J. Plant Pathol. 126:417-422.

Hussey, R., and Barker, K. 1973. A comparison of methods for collecting inocula of Meloidogyne spp. including a new technique. Plant Dis. Rep. 57: 1025-1028.

Insam, H., and Seewald, M. S. 2010. Volatile organic compounds (VOCs) in soils. Biol. Fertil. Soils 46:199-213.

Jardim, I. N., Oliveira, D. F., Silva, G. H., Campos, V. P., and de Souza, P. E. 2018. (E)-cinnamaldehyde from the essential oil of Cinnamomum cassia controls Meloidogyne incognita in soybean plants. J. Pest Sci. 91:479-487.

Jenkins, W. 1964. A rapid centrifugal-flotation technique for separating nematodes from soil. Plant Dis. Rep. 48:692.

Jones, J. T., Haegeman, A., Danchin, E. G., Gaur, H. S., Helder, J., Jones, M. G., Kikuchi, T., Manzanilla-López, R., Palomares-Rius, J. E., and Wesemael, W. M. 2013. Top 10 plant-parasitic nematodes in molecular plant pathology. Mol. Plant Pathol. 14:946-961.

Kokalis-Burelle, N., Butler, D. M., Hong, J. C., Bausher, M. G., McCollum, G., and Rosskopf, E. N. 2016. Grafting and Paladin Pic-21 for nematode and weed management in vegetable production. J. Nematol. 48:231.

Leff, J. W., and Fierer, N. 2008. Volatile organic compound (VOC) emissions from soil and litter samples. Soil Biol. Biochem. 40:1629-1636.

Lord, J. S., Lazzeri, L., Atkinson, H. J., and Urwin, P. E. 2011. Biofumigation for control of pale potato cyst nematodes: Activity of brassica leaf extracts and green manures on Globodera pallida in vitro and in soil. J. Agric. Food Chem. 59:7882-7890.

Loreto, F., Dicke, M., Schnitzler, J. P., and Turlings, T. C. 2014. Plant volatiles and the environment. Plant Cell Environ. 37:1905-1908.

Mojtahedi, H., Santo, G., Wilson, J., and Hang, A. 1993. Managing Meloidogyne chitwoodi on potato with rapeseed as green manure. Plant Dis. 77:42-46.
Neves, W. S., Freitas, L. G., Coutinho, M. M., Parreira, D. F., Ferraz, S., and Costa, M. D. 2007. Biofumigação do solo com espécies de brássicas para o controle de Meloidogyne javanica. Nematol. Bras. 31:195-201.

Ngala, B. M., Haydock, P. P., Woods, S., and Back, M. A. 2015. Biofumigation with Brassica juncea, Raphanus sativus and Eruca sativa for the management of field populations of the potato cyst nematode Globodera pallida. Pest Manage. Sci. 71:759-769.

NIST. 2016. Chemistry Webook-National Institute of Standards and Technology, Gaithersburg, MD.

Ntalli, N. G., Ferrari, F., Giannakou, I., and Menkissoglu-Spiroudi, U. 2011. Synergistic and antagonistic interactions of terpenes against Meloidogyne incognita and the nematicidal activity of essential oils from seven plants indigenous to Greece. Pest Manage. Sci. 67:341-351.

Oka, Y. 2010. Mechanisms of nematode suppression by organic soil amendmentsA review. Appl. Soil Ecol. 44:101-115.

Oka, Y., Nacar, S., Putievsky, E., Ravid, U., Yaniv, Z., and Spiegel, Y. 2000a Nematicidal activity of essential oils and their components against the rootknot nematode. Phytopathology 90:710-715.

Ploeg, A. 2008. Biofumigation To Manage Plant-Parasitic Nematodes. Pages 239-248 in: Integrated Management and Biocontrol of Vegetable and Grain Crops Nematodes. A. Ciancio and K. G. Mukerji, eds. Springer Netherlands, Dordrecht, The Netherlands.

Ploeg, A. T. 2000. Effects of amending soil with Tagetes patula cv. Single Gold on Meloidogyne incognita infestation of tomato. Nematology 2:489-493.

Ploeg, A. T., and Stapleton, J. J. 2001. Glasshouse studies on the effects of time, temperature and amendment of soil with broccoli plant residues on the infestation of melon plants by Meloidogyne incognita and M. javanica. Nematology 3: 855-861.

Potgieter, C., De Beer, M., and Claassens, S. 2013. The effect of canola (Brassica napus) as a biofumigant on soil microbial communities and plant vitality: A pot study. S. Afr. J. Plant Soil 30:191-201.

Regente, M. C., and De La Canal, L. 2000. Purification, characterization and antifungal properties of a lipid-transfer protein from sunflower (Helianthus annuus) seeds. Physiol. Plant. 110:158-163.

Roubtsova, T., López-Pérez, J.-A., Edwards, S., and Ploeg, A. 2007. Effect of broccoli (Brassica oleracea) tissue, incorporated at different depths in a soil column, on Meloidogyne incognita. J. Nematol. 39:111-117.

Silva, J. C. P., Campos, V. P., Freire, E. S., Terra, W. C., and Lopez, L. E. 2017. Toxicity of ethanol solutions and vapours against Meloidogyne incognita. Nematology 19:271-280.

Silva, W. R., Machado, A. R., Campos, V. A., Zeri, A., Campos, V. P., and Oliveira, D. F. 2013. Volatile organic compounds for the control of Meloidogyne exigua in Coffea arabica. Trop. Plant Pathol. 38:375-386.

Tainter, C., Ni, Y., Shi, L. a., and Skinner, J. 2012. Hydrogen bonding and $\mathrm{OH}$ stretch spectroscopy in water: Hexamer (cage), liquid surface, liquid, and ice. J. Phys. Chem. 4:12-17.

Terra, W. C., Campos, V. P., Martins, S. J., Costa, L. S. A. S., da Silva, J. C. P., Barros, A. F., Lopez, L. E., Santos, T. C. N., Smant, G., and Oliveira, D. F 2018. Volatile organic molecules from Fusarium oxysporum strain 21 with nematicidal activity against Meloidogyne incognita. Crop Prot. 106:125-131.

Terra, W. C., Campos, V. P., Pedroso, M. P., da Costa, A. L., Freire, E. S., de Pinto, I. P., da Silva, J. C. P., Lopez, L. E., and Santos, T. C. N. 2017. Volatile molecules of Fusarium oxysporum strain 21 are retained in water and control Meloidogyne incognita. Biol. Control 112:34-40.

Tiyagi, S. A., and Ajaz, S. 2004. Biological control of plant parasitic nematodes associated with chickpea using oil cakes and Paecilomyces lilacinus. Indian J. Nematol. 34:44-48.

Trudgill, D. L., and Blok, V. C. 2001. Apomictic, polyphagous root-knot nematodes: Exceptionally successful and damaging biotrophic root pathogens. Annu. Rev. Phytopathol. 39:53-77.

Vervoort, M. T., Vonk, J. A., Brolsma, K. M., Schütze, W., Quist, C. W., de Goede, R. G., Hoffland, E., Bakker, J., Mulder, C., and Hallmann, J. 2014. Release of isothiocyanates does not explain the effects of biofumigation with Indian mustard cultivars on nematode assemblages. Soil Biol. Biochem. 68 200-207.

Wen, Y., Meyer, S. L., Masler, E. P., Zhang, F., Liao, J., Wei, X., and Chitwood, D. J. 2013. Nematotoxicity of drupacine and a Cephalotaxus alkaloid preparation against the plant-parasitic nematodes Meloidogyne incognita and Bursaphelenchus xylophilus. Pest Manage. Sci. 69:1026-1033.

Wheatley, R. E. 2002. The consequences of volatile organic compound mediated bacterial and fungal interactions. Antonie Leeuwenhoek 81:357-364.

Zasada, I., and Ferris, H. 2003. Sensitivity of Meloidogyne javanica and Tylenchulus semipenetrans to isothiocyanates in laboratory assays. Phytopathology 93:747-750.

Zou, C.-S., Mo, M.-H., Gu, Y.-Q., Zhou, J.-P., and Zhang, K.-Q. 2007. Possible contributions of volatile-producing bacteria to soil fungistasis. Soil Biol. Biochem. 39:2371-2379. 